\title{
Mycosis Fungoides and Sezary Syndrome TNM Finding v8
}

National Cancer Institute

\section{Source}

National Cancer Institute. Mycosis Fungoides and Sezary Syndrome TNM Finding v8. NCI Thesaurus. Code C141304.

A finding about one or more characteristics of mycosis fung oides and Sezary syndrome, following the rules of the TNM AJCC V8 classification system. This classification is based on the ISCL/EORT C revision to the classification of mycosis fungoides and Sezary syndrome. (from AJCC 8th Ed.) 